\title{
Reliability of linear distance measurements of surgical implants and gutta percha lengths used in endodontic treatment with standardized digital radiography
}

\author{
Mehmet Colak ${ }^{1}$, Ozkan Adiguzel ${ }^{2}$, Ceren Aktuna Belgin'1, Seda Falakaloglu², Zeki \\ Akkus $^{3}$
}

${ }^{1}$ Dicle University, Faculty of Dentistry, Department of Dentomaxillofacial Radiology, Diyarbakir, Turkey

2 Dicle University, Faculty of Dentistry, Department of Endodontics, Diyarbakir, Turkey

3 Dicle University, Faculty of Medicine, Department of Biostatistics, Diyarbakir, Turkey

\section{Correspondence:}

Dr. Mehmet COLAK

Dicle University, Faculty of

Dentistry, Department of

Dentomaxillofacial Radiology,

21280, Diyarbakir, TURKEY.

e-mail:mcolak1957@hotmail.com

Received 4 October 2016

Accepted 10 January 2017

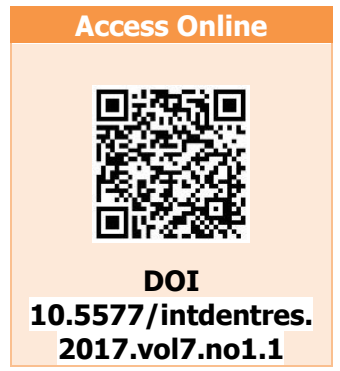

\section{Introduction}

In dentistry, radiographic images are the most commonly used method for determining the working size in root canal treatments and surgical implant applications. In recent years, developments in digital radiography have provided diagnostic advantages

\begin{abstract}
Aim: The length of gutta percha cones used in endodontic treatment and of dental implants used in dental surgery were compared with the lengths of periapical radiographs taken with phosphor plates and panoramic radiographs.

Methodology: This study included 120 radiographs: 60 panoramic and 60 periapical radiographs, 30 of dental implants and 30 of gutta percha cones. The actual length and width measurements of both implants and gutta percha cones were compared with panoramic radiographs and length and width measurements on periapical radiographs.

Results: When the measurements made on panoramic and periapical radiographs taken with phosphor plates were evaluated statistically, it was apparent that the periapical radiographs taken with phosphor plate showed less magnification error than did those taken with the panoramic technique.

Conclusions: Clinicians should be aware of the limitations of the techniques used in clinical dentistry, comparing data obtained with digital radiographs of surgical implants and gutta percha cones.
\end{abstract}

Keywords: Implant length, gutta percha length, standardized digital radiography, dental $\mathrm{x}$-ray measurement

How to cite this article: Colak M, Adiguzel O, Aktuna Belgin C, Falakaloglu S, Akkus Z. Reliability of linear distance measurements of surgical implants and gutta percha lengths used in endodontic treatment with standardized digital radiography. Int Dent Res 2017;7:1-5.
(1). However, the presence of anatomical formations such as the zygomatic arch, maxillary sinus, foramen mentale, and mandibular canal makes images difficult to interpret and causes many clinicians to make mistakes with two-dimensional films. Additionally, the radiation dose associated with repeated radiography may create a sense of insecurity in the patient; in particular, positioning 
patients with a gag/vomit reflex may prove difficult (2-5). As a result of such misinterpretations, dental treatments may fail. For example, failure to properly determine duct size may lead to pain, intra-canal medication overflow into periradicular tissues, infection, and eventually, tooth retraction (6).

Direct digital radiography has many advantages compared with conventional radiography, such as faster imaging, lower radiation dose, and the potential for patient archival records. Versteeg et al. reported that a direct digital sensor system in endodontics and implants was an important application when investigating the efficacy of intraoral radiography in clinical dentistry (7). Borg et al. reported that the intraoral phosphor plate imaging system provided reliable endodontic measurements even at the lowest doze (8).

Only a few reports in the literature draw comparisons between measurements made on panoramic radiographs and those made on periapical radiographs taken with phosphor plates. Griffith et al. reported that the most accurate results in determining root length during root canal treatment were provided by conventional radiography (9). Ong et al. found no statistically significant difference between digital radiography and conventional radiographs in root canal measurement in their studies; they reported similar results with both techniques (10). In this study, we compared lengths of dental implants and gutta percha cones in terms of actual lengths versus values determined from periapical radiographs taken with panoramic and phosphor plates.

\section{Materials and Methods}

This study was performed in 120 patients who were referred to Dicle University, Faculty of Dentistry, Department of Oral and Maxillofacial Radiology. Before the study, the patients provided informed consent. Moreover, approval was received from the ethics committee of Dicle University Dentistry Faculty.

Patients were divided into two groups: patients with root canal treatment, and those with dental implant therapy. Each group was divided into two subgroups, one for panoramic radiographs and the other for periapical radiography with phosphor plates. To minimize distortion and magnification conditions in the panoramic radiograph scan, patients were placed in a fixed position in the device relative to a vertical line parallel to the sagittal plane and to a horizontal line passing through the Frankfurt plane parallel to the ground. The principle of 'as low as reasonably achievable' (ALARA) exposure was followed in all radiographs. Digital panoramic films (Progeny, Midmark Company, USA) were taken using a $0.5-\mathrm{mm}$ focal spot, $3.2-\mathrm{mm}$ filtration, $70 \mathrm{kVp}, 10 \mathrm{~mA}$, and 15.9-s scanning parameters. The scans were made with the standard panoramic module of the device. For the periapical radiographs, images of the dental implant and gutta percha were taken with a \# 2 standard phosphor plate (Photostimulable phospor plate, PSPIX, Acteon, France) $3 \times 4 \mathrm{~cm}$ in size. Periapical radiographs were taken with a paralleling technique using dental radiograph equipment (Planmeca ProX, Helsinki, Finland). Scanning parameters were $70 \mathrm{kVp}, 7 \mathrm{~mA}$, and $0.08 \mathrm{~s}$.

Single-rooted teeth in the mandible with indications for endodontic treatment were included in the study. The Reciproc R25 (VDW, Munich, Germany) rotary file system with reciprocal motion was used, and a Reciproc R25 gutta percha cone, 28 $\mathrm{mm}$ in length was placed as the master cone in root canal preparation. Using software and the digital image, the gutta percha length was measured in triplicate with Progeny Imaging (ver. 1.11.4.0), and the average was taken.

The actual known lengths and widths of 60 dental implants were recorded. At 3 months after the surgical implant application, periapical radiographs of 30 implants and digital panoramic radiographs of 30 implants were taken before the healing head was attached. Size and width were determined from the images obtained. Using software and the digital images, the gutta percha length was measured in triplicate with Progeny Imaging (ver. 1.11.4.0), and the average was taken.

\section{Statistical Analysis}

The distribution of the data was assessed for normality using the Shapiro-Wilk test in comparisons of measurements of the gutta percha. Based on these results, Student's t-test (one-sample t-test) was used. For comparisons of the dental implant measurements, the Shapiro-Wilk test showed a normal distribution, so an independentgroups Student's t-test was used. The comparison between the two techniques was analyzed with an independent two-sample t-test. All statistical analyses were performed using the SPSS software (ver. 20.0).

\section{Results}

The actual size of the Resiproc R25 gutta percha was assumed to be $28 \mathrm{~mm}$. The average size in periapical radiographs of the 30 gutta percha cones in the control group was $28.35, \mathrm{~mm}$ and the average size with panoramic radiography was 29.60 $\mathrm{mm}$. Results from the radiographic techniques were 
compared using an independent two-sample t-test; a statistically significant difference was observed $(p<0.05)$. There was no statistically significant difference between the actual size of the gutta percha and the mean size by periapical radiography $(P>0.05)$. However, a statistically significant difference was found between the actual size of the gutta percha and the mean size estimated from the panoramic radiographs $(p<0.001 ;$ Table 1$)$.

The comparison of the true average heights and diameters of the implants and the measured heights and diameters from the panoramic radiograph are shown in Table 2 . The actual average length of the 30 dental implants was $9.883 \mathrm{~mm}$, and the actual average diameter was $4.126 \mathrm{~mm}$. The mean height measured from the panoramic radiographs of the 30 implants was $11.36 \mathrm{~mm}$, and the mean diameter was $4.537 \mathrm{~mm}$. There were statistically significant differences between the actual lengths and diameters of the implants and the measured lengths and diameters from the panoramic radiographs $(p<0.001)$.

The average actual heights and diameters of the other 30 implants and the measured values from periapical radiographs are shown in Table 3. The average length of the 30 dental implants was 10.66 $\mathrm{mm}$, and the average diameter was $4.006 \mathrm{~mm}$. The average length of the implants from the periapical radiographs was $11.73 \mathrm{~mm}$, and the average diameter was $4.177 \mathrm{~mm}$. There were statistically significant differences between the actual lengths of the implants and the measured lengths based on the periapical radiographs $(p<0.05)$. However, there was no statistically significant difference between the actual average diameter and the average diameter from the periapical radiographs $(p>0.05)$.

Table 1. Periapical and panoramic radiographic measurements of gutta percha $(\mathrm{mm})$

\begin{tabular}{|l|c|c|c|c|}
\hline Gutta percha & Number & Actual size $(\mathbf{m m})$ & Average & $p$ \\
\hline $\begin{array}{l}\text { Measurement } \\
\text { in periapical }\end{array}$ & 30 & 28 & $28.35 \pm 0.96$ & $p>0.05$ \\
\hline $\begin{array}{l}\text { Measurement } \\
\text { in panoramic }\end{array}$ & 30 & 28 & $29.60 \pm 0.88$ & $p<0.001$ \\
\hline
\end{tabular}

Table 2. Length and size of the implants in panoramic radiographs $(\mathrm{mm})$

\begin{tabular}{|c|c|c|c|c|}
\hline & Number & $\begin{array}{l}\text { Average actual } \\
\text { diameter }(\mathrm{mm})\end{array}$ & $\begin{array}{l}\text { Average } \\
\text { measured } \\
\text { diameter }\end{array}$ & p \\
\hline $\begin{array}{l}\text { Length of } \\
\text { implants }\end{array}$ & 30 & $9.883 \pm 1.096$ & $11.36 \pm 1.628$ & $p<0.001$ \\
\hline Size of implants & 30 & $4.126 \pm 0.311$ & $4.537 \pm 0.378$ & $p<0.001$ \\
\hline
\end{tabular}

Table 3. Length and diameter of implants in periapical radiographs ( $\mathrm{mm})$

\begin{tabular}{|l|c|c|c|c|}
\hline & Number & $\begin{array}{c}\text { Average actual } \\
\text { diameter }\end{array}$ & $\begin{array}{c}\text { Average } \\
\text { measured } \\
\text { diameter }\end{array}$ & p \\
\hline $\begin{array}{l}\text { Length of } \\
\text { implants }\end{array}$ & 30 & $10.66 \pm 1.652$ & $11.73 \pm 1.830$ & $p<0.05$ \\
\hline $\begin{array}{l}\text { Size of } \\
\text { implants }\end{array}$ & 30 & $4.006 \pm 0.39$ & $4.177 \pm 0.385$ & $p>0.05$ \\
\hline
\end{tabular}




\section{Discussion}

In planning root canal treatments and other surgical interventions, it is important for dentists to understand the neighborhood and distances to anatomical formations in the region. The reliability and accuracy of the radiographs taken for these purposes are important. According to the results of this study, image sizes obtained with the periapical radiography technique using phosphor plates were closer to the actual dimensions than those from panoramic radiographs.

The magnification contrast ratio specified by the manufacturer for the panoramic device used here was a maximum of $1.2(20 \%)$. From our study, when the image magnification obtained in the panoramic views of the gutta percha cones was analyzed, a range of 1.007-1.120 was observed. When the image magnification of the implant size obtained in the panoramic view was analyzed, magnitude ranging from 1.025 to 1.2 was observed. When the image magnification of the implant diameters was analyzed, magnitude ranging from 1.05 to 1.2 was observed.

Conover et al. stated that, in an in vitro study using dental radiographs and a periapical radiography technique with phosphor plates, the measurements in both techniques were equal, when comparing dimensional measurements (11). Devlin et al. reported that with automatic measurements of image dimensions, the magnitude in the vertical direction showed less variation than did that horizontally (12). Park reported that the magnitude of magnification of the vertical dimension in the panoramic image of an implant was $126.8 \%$, on average, and the magnitude of the magnification of the anatomical arch showed a minimum of $119.4 \%$ and a maximum of $130.8 \%$ (13). Vazquez et al. (14) reported that digital panoramic radiography was highly reliable in premolar and molar segments in a pre-operative evaluation of implant lengths.

Vazquez et al. noted that the accuracy of the magnification provided by the manufacturer was important in assessing the reliability of the vertical magnification of the mandibular implants in the panoramic radiography technique (15). Langlois et al. stated that there was no statistical difference $(p>0.05)$ in the evaluation of the length measurements obtained before and after digitizing periapical and panoramic radiographs in an in vitro study (16). Haghnegahdar et al. noted that in evaluating the vertical length of the posterior mandible in panoramic radiographs, the results exaggerated linear measurements but that this was negligible, with a magnification of 1.29 (17). Mohtavipour et al. found no significant difference between the measured values when comparing conventional and digital radiography in a study of the channel neck (18). Wakoh et al. reported that they obtained more accurate implant measurements with a conventional periapical $\mathrm{X}$-ray technique in vitro than with three other techniques (panoramic, conventional tomography, medical tomography) (19). May et al. reported that percussion, inspiration, and conventional periapical radiographs were the most commonly used methods of assessing implant compliance, but that their accuracy was limited (20). Yim et al. reported that when they analyzed the image magnification in dental implant surgery, the magnitude in panoramic images ranged from 1.09 to 1.28 , depending on the location of the teeth (21). Loushine et al. stated that it was important to calibrate the devices to obtain 'correct' results (22). The films are two-dimensional and magnifications or distortions may occur in the x-ray images. Periapical radiographs taken with phosphor plates showed less magnification error than do panoramic radiographs. Reasons for this include the flexibility of phosphor plaque sensors, the parallel placement of the teeth, and the ability to take a radiograph with a parallel technique, with minimal distance between the tooth and the film. In this study, the phosphor plate sensor was wireless and flexible, and more than one could be used; the irradiation time was $0.08 \mathrm{~s}$, and the reduced magnification was the biggest advantage of this technique over the panoramic technique.

\section{Conclusions}

In this study, we sought to examine techniques used in clinical dentistry, comparing data obtained with digital radiographs of surgical implants and gutta percha cones, as used in endodontic treatments. Clinicians should be aware of the limitations of the techniques on which they rely.

\section{Acknowledgments}

This work was supported by Research Fund of the Dicle University. Project Number: 14-DH-65

\section{References}

1. Wenzel A. Computer-aided image manipulation of intraoral radiographs to enhance diagnosis in dental practice: a review. Int Dent J 1993;43:99-108.

2. Yücel AÇ, Şaklar F. Kök kanal boyunun belirlenmesinde dijital radyografilerin diğer yöntemlerle karşılaştırıması. A.Ü. Diş Hek. Fak. Derg 2005;32(3):201-6.

3. Parlar S. Endodontide kök kanal boyu saptama yöntemleri. Doktora Tezi. Ege Üniv Diş Hek. Fak. İzmir 2002. 
4. Ottel W. Kanal boyu saptama yöntemleri. Doktora tezi. Ege Üniv Diş Hek.Fak. İzmir 2002.

5. Alay G. Endodontide kök kanal boyu saptama yöntemleri. Doktora tezi. Ege Üniv Diş Hek.Fak. İzmir 2003.

6. Certosimo FJ, Milos MF, Walker T. Endodontic working length determination: where does it end? Gen Dent 1999;47:281-6.

7. Versteeg $\mathrm{CH}$, Sanderink GC, van der Stelt PF. Efficacy of digital intra-oral radiography in clinical dentistry. J Dent 1997;25:215-24. Crossref

8. Borg E, Grondahl HG. Endodontic measurements in digital radiographs acquired by a photostimulable, storage phosphor system. Endod Dent Traumatol 1996;12:20-4. Crossref

9. Griffiths BM, Brown JE, Hyatt AT, Linney AD. Comparison of three imaging techniques for assessing endodontic working length. Int Endod J 1992;25:279-87. Crossref

10. Ong EY, Pitt Ford TR. Comparison of radio visio graphy with radiographic film in root length determination. Int Endod J 1995;28:25-9. Crossref

11. Conover GL, Hildebolt CF, Yokoyama-Crothers N. Comparison of linear measurements made from storage phosphor and dental radiographs. Dentomaxillofac Radiol. 1996 Nov;25(5):268-73. Crossref

12. Devlin $\mathrm{H}$, Yuan J. Object position and image magnification in dental panoramic radiography: a theoretical analysis. Dentomaxillofac Radiol. 2013;42(1):29951683. Crossref

13. Park JB. The evaluation of digital panoramic radiographs taken for implant dentistry in the daily practise. Med Oral Patol Oral Cir Bucal. 2010 Jul 1; 15(4):663-6. Crossref

14. Vazquez $L$ et al. Accuracy of vertical height measurements on direct digital panoramic radiographs using posterior mandibular implants and metal balls as refence objects. Dentomaxillofac Radiol 2013;42(2):2011042. Crossref

15. Vazquez $L$ et al. Reliability of the vertical magnification factor on panoramic radiographs: clinical implications for posterior mandibular implants. Clin Oral Impl Res 2011;22:1420-5. Crossref

16. Langlois $\mathrm{CO}$ et al. Accuracy of linear measurements before and after digitizing periapical and panoramic radiography images. Braz Dent J 2011, 22(5):404-9. Crossref

17. Haghnegahdar A, Bronoosh P. Accuracy of linear vertical measurements in posterior mandible on panoramic view. Dent Res J 2013;10(2):220-4. Crossref

18. Mohtavipour ST, Dalili Z, Azar NG. Direct digital radiography versus conventional radiograhy for estimation of canal length in curved canals. Imaging Sci Dent 2011;41:7-10. Crossref

19. Wakoh $\mathrm{M}$ et al. Reliabilty of linear distance mesurement for dental implant length with standardized periapical radiographs. Bull Tokyo Dent Coll. 2006;47(3):105-15. Crossref

20. May KB et al. The precision of fit at the implant prosthodontic interface. J Prosthet Dent 1997;77:497-502. Crossref

21. Yim JH et al. Analysis of digitalized panorama and cone beam computed tomographic image distortion for the diagnosis of dental implant surgery. J Craniofac Surg 2011;22:669-73. Crossref

22. Loushine RJ, Weller RN, Kimbrough WF, Potter BJ. Measurement of the endodontic file lengths: calibrated versus uncalibrated digital images. J Endod 2001;27: 77981. Crossref 